American Journal of Life Sciences
2019; 7(6): 120-127
http://www.sciencepublishinggroup.com/j/ajls
doi: 10.11648 j.ajls.20190706.14
ISSN: $2328-5702$ (Print); ISSN: $2328-5737$ (Online)

\title{
Assessment of Potential and Constraints of Honey Production in Godere District, Southwest Ethiopia
}

\author{
Gemechis Legesse Yadeta \\ Oromia Agricultural Research Institute, Holeta Bee Research Center, Holeta, Ethiopia
}

Email address:

glgesseyadeta@gmail.com

\section{To cite this article:}

Gemechis Legesse Yadeta. Assessment of Potential and Constraints of Honey Production in Godere District, Southwest Ethiopia. American Journal of Life Sciences. Vol. 7, No. 6, 2019, pp. 120-127. doi: 10.11648/j.ajls.20190706.14

Received: September 17, 2019; Accepted: November 4, 2019; Published: December 2, 2019

\begin{abstract}
The study was conducted in Godere district, southwestern Ethiopia to assess the potential, opportunities and constraints in honey production. 120 beekeepers were selected and interviewed from two kebeles using semi structured questionnaire. Participatory discussions with key informant at village levels and Zone and District level bee experts and extension workers were also held to generate primary data. All the interviewed household heads were male headed, with average age of 37.42 years. The average number of traditional beehive holding was 28.4. It was found out that there are two to three honey production seasons in the district. The average productivity of colonies in traditional log beehives was $24.2+9.33$. The major opportunities to engage on honeybee beekeeping were long beekeeping experience, existence of huge natural resource that includes honeybee flora, honeybee colonies, high productivity and increasing demand of honey in the area. About $93.25 \%$ of their produce (totally crude honey) was sold in nearby markets. $94.4 \%$ of respondents sold their honey immediately after harvest, while the remaining $5.6 \%$ stored for more than a month. $76.2 \%$ of the producers largely sold their honey in the nearest local market, only less than $24 \%$ of the respondents transport their honey to Meti town. The price difference between the village market and Meti was as high as $70 \%$. The major honey buyers reported by the producers are the collectors $(82.45 \%)$ and tej brewers (16.32\%) in Godere district. Generally, the honey production system in the area is traditional forest beekeeping with a lot of constraints. Therefore, it needs systematic approach to tackle all the problems in the whole system starting from input supply all along to marketing. Provision of extension services to upgrade knowledge, develop skills and introduction of improved technologies needs due attention.
\end{abstract}

Keywords: Beekeeping, Constraints, Gambella, Godere, Honey Production Potential

\section{Introduction}

The diversified agro-climatic conditions with various honeybee floras have created a favorable environment for beekeeping practice in Ethiopia. The country has the largest bee population in Africa with over 10 million bee colonies, out of which about 7.5 million are confined in hives and the remaining are feral colonies [1]. However, recently it was reported that only about 5.92 million colonies were hived in the rural sedentary areas of the country [2]. Moreover, about 1.4 million smallholding households are engaged in keeping bees as a mean of additional income generating activity [3]. These, among many other factors, has made the country among the top honey and beeswax producing countries in the world [4]. Beekeeping is creating job opportunities for many people both in rural and urban areas. A significant number of people are currently engaged in honey and beeswax collection, "tej" making, honey and beeswax processing and marketing [5].

The honey production system of Ethiopia is characterized by almost wholly traditional beekeeping even though a lot of efforts have been made by different stakeholders to transform from traditional practice to the improved ones. For instance, the number of traditional hives in 2009 accounted for nearly $97.5 \%$, while the 2017 data shows $95.37 \%$ [2, 6]. Frame (box) hive and intermediate beekeeping only account $3.34 \%$ and $1.3 \%$, respectively [2]. Therefore, the apiculture subsector lacks the necessary financial, technological and extension support [7]. The honey marketing is also conducted in a traditional manner that lacks proper structure and legality; lengthy chain of actors that widens gap for the access of producers to bigger and better paying markets [8]. 
Gambella region in general and Godere district in particular are one of the areas with huge beekeeping potential. The region was reported to have about 86,300 colonies of bee [9]. About $40 \%$ of the district area is covered with dense forest called Gelesha forest, which covers about 120,000 hectares of land [10]. Moreover, this district is known for its high coffee and spice production. These are expected to provide a good opportunity to have various honey types and high production potential in the area. Therefore, this study was designed to assess the socioeconomic importance, potential, opportunities and challenges of beekeeping in Godere district.

\section{Materials and Methods}

\subsection{Description of the Study Area}

The study was conducted in March, 2018 in Godere district, in Mejang zone found in the Gambella Regional State. The district is located between $7^{\circ} 08^{\prime}-7^{\circ} 23^{\prime}$ latitude and $34^{\circ} 52^{\prime}-35^{\circ} 25^{\prime}$ longitude. It also has an altitude ranging from 500 to $2400 \mathrm{~m}$ above sea level [11]. The climate of the district is a hot and humid type. It receives high rainfall between mid-March to October and low rainfall from November to February. The annual rainfall amount of the area ranges from $900 \mathrm{~mm}$ to above $2200 \mathrm{~mm}$ but the majority of the areas receive over $1500 \mathrm{~mm} /$ annum. The lowest mean monthly temperature is $13.2^{\circ} \mathrm{C}$ and the highest mean monthly temperature is $33.1^{\circ} \mathrm{C}$ with an average temperature of $22.2^{\circ} \mathrm{C}$
[11]. The soil of the district is reddish brown, well drained and clay in texture [12].

\subsection{Method of Data Collection and Analysis}

Based on the information obtained from secondary data of district Agricultural office, sampling was conducted in two kebeles (i.e., smallest administrative unit), kabo and Meti Zuria selected based on the history of honey production and its representativeness to the district beekeeping potential areas. Accordingly, one hundred twenty beekeeping households were selected, 60 from kabo and 60 from Meti Zuria kebeles.

The selected beekeepers were interviewed by using semistructured questionnaires which was pre-tested, and translated into local language (Amharic). The primary data such as socioeconomic parameters, numbers of bee colonies, vernacular names of honeybee flora and their flowering calendar, types of beehives, annual honey yield of single colony, etc. were collected from respondent farmers through the questionnaire. Moreover, collection of other important data like potentials and constraints of honey production and marketing systems, honey harvesting frequency and seasons and way of harvesting was also supported by group discussions with experienced beekeepers and key informants. The collected data were coded and tabulated for analysis. Descriptive statistics (i.e., mean, percentage, ranking and standard deviation) using SPSS version 16.0 was used to analyze the collected data.

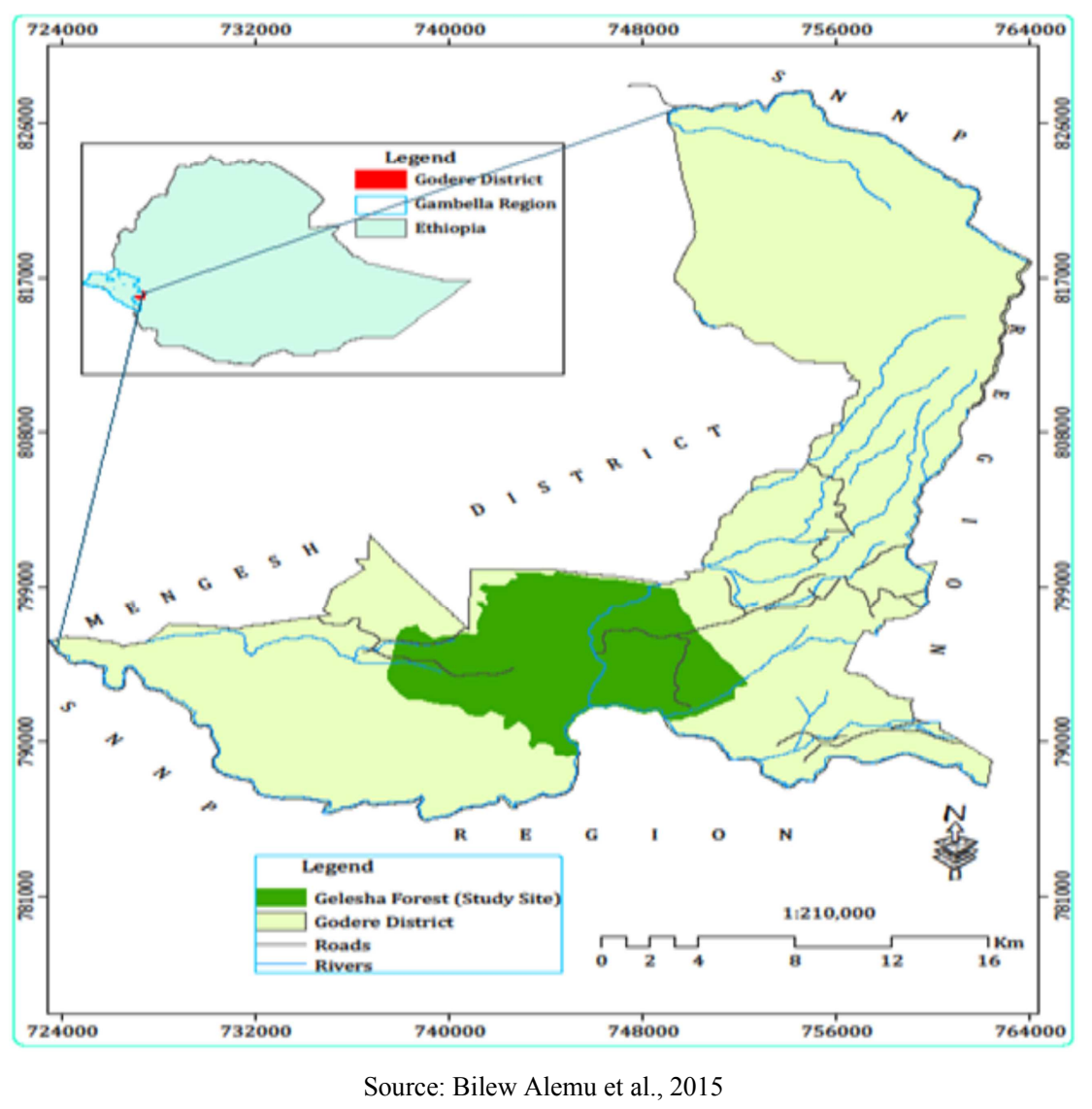

Figure 1. Map of study area: Godere district, Gambella Region. 


\section{Results}

\subsection{Socioeconomic Characteristics of the Beekeepers}

This survey result showed that beekeeping is traditionally practiced starting from childhood among the rural communities in Godere district. The mean age of the beekeepers in the district was 37.42 years, ranging from 17 year to 73 years (Table 1). However, beekeeping in the study area is exclusively $(100 \%)$ men's activity. The beehive holding of the beekeepers showed that almost all respondents use only traditional $\log$ hives. The average number of traditional beehive holdings was 28 beehives, ranging between 12 and 54 . Only less than $2 \%$ of the beekeepers reported they had transitional and/or frame hives in addition to the $\log$ hives (Table 1).

Table 1. Socioeconomic characteristic of the household beekeepers.

\begin{tabular}{llll}
\hline Variables & Min. & Max. & Mean+ SD \\
\hline Age of the beekeepers & 17 & 73 & $37.42+12.54$ \\
Years of beekeeping experiences & 3 & 31 & $19.25+8.56$ \\
$\begin{array}{l}\text { Number of hives owned } \\
\text { Traditional hives }\end{array}$ & 12 & 54 & $28.4+13.26$ \\
Transitional hives & 1 & 3 & $0.13+0.07$ \\
Frame hives & 1 & 4 & $0.22+0.05$ \\
\hline
\end{tabular}

Source: own data

\subsection{Honeybee Plants}

This study showed that the composition of honeybee plants in the area comprise of trees, shrubs, herbs and cultivated crops which are a source of nectar and/or pollen. The common/ vernacular and scientific names of the major honey plants identified in the area with their flowering periods are given in Table 2.

The dominant honey plants known and listed by the respondents at Kabo, the highland around the Gelesha forest include Schefflera abyssinica, Croton macrostachyus, Coffee arabica, Vernonia spp., Syzygium guineense, Cordia africana, Albizia spp., reported as predominantly abundant in the forests and are important for honey production in different seasons. Moreover, important annual herbs like Guizotia scabra, Bidens pychloma and cultivated pulse crops were mentioned. Similarly, respondents in Meti Zuria (majorly the Mejang community members) also mentioned plants species like Aningeria adolfi friedrichi, Albizia schimperiana, C. africana, etc as dominantly abundant and important honey plants. Moreover, cultivated crops like $S$. bicolor (Shurii), mango and coffee also contribute to honey production.

\subsection{Beekeeping Practices in Godere District}

The findings of this study indicated that beekeeping in Godere district is characterized by little or no practice of colony monitoring and maintenance as the respondents have reported they practiced any kind of external and/or internal colony inspection. Only from experience of generations, they know when to prepare, smoke and hang their log beehives to bait swarms. The respondents indicated that there are two seasons a year to catch swarms. But only $37.4 \%$ of the beekeepers reported they hung bait hives twice a year, while $62.6 \%$ hung once in a year to catch swarms.

In Godere, there are 2 to 3 honey harvesting seasons depending on the vegetation coverage and the prevailing climatic factors. The overall feature of frequency of honey harvesting in Godere showed that about $62 \%$ indicated that they harvested honey twice a year, while about $38 \%$ reported three harvesting seasons a year. It was also found out that the productivity of honeybee colonies is very high. The average crude honey yield per traditional hive per year is about $24.2 \mathrm{~kg}$ (ranging between 15 and $40 \mathrm{~kg}$ ).

Table 2. Major honeybee plants and their flowering calendar in Godere District.

\begin{tabular}{|c|c|c|c|c|c|c|c|c|c|c|c|c|c|}
\hline \multirow{2}{*}{ Local/common name } & \multirow{2}{*}{ Scientific name } & \multicolumn{12}{|c|}{ Flowering period/months } \\
\hline & & Sept & Oct & Nov & Dec & Jan & Feb & Mar & Apr & May & Jun & Jul & Aug \\
\hline Wanza $^{1} / \mathrm{Di}^{\prime} \mathrm{o}^{2}$ & Cordia africana & $\checkmark$ & & & & & & & & & & & $\checkmark$ \\
\hline Sesa $^{1} /$ Somay $^{3}$ & Albizia schimperiana & & & & & & & & $\checkmark$ & $\checkmark$ & $\checkmark$ & & \\
\hline Bisana $^{1} /$ Shomo $^{2}$ & Croton macrostachyus & & & & & & & & & $\checkmark$ & $\checkmark$ & & \\
\hline Kerero $^{1} / \mathrm{Sha}^{\prime}{ }^{2} / \mathrm{Gommo}^{3}$ & Aningeria adolfi friedrichi & & & & $\checkmark$ & $\checkmark$ & $\checkmark$ & & & & & & \\
\hline Girawa $^{1}$ & Vernonia spp. & & & & & $\checkmark$ & & & & & & & \\
\hline Buna $^{1}$ & Coffee arabica & & & & & $\checkmark$ & $\checkmark$ & & & & & & \\
\hline Qey Beharzaf $^{1}$ & Eucalyptus camaldulensis & $\checkmark$ & $\checkmark$ & $\checkmark$ & $\checkmark$ & $\checkmark$ & $\checkmark$ & $\checkmark$ & $\checkmark$ & $\checkmark$ & $\checkmark$ & $\checkmark$ & $\checkmark$ \\
\hline Dokma $^{1} /$ Yino $/$ Shoto $^{2}$ & Syzygium guineense & & & & $\checkmark$ & $\checkmark$ & & & & & & & \\
\hline Geteme $^{1} /$ Menjo $^{2}$ & Schefflera abyssinica & & & & & & & $\checkmark$ & $\checkmark$ & $\checkmark$ & & & \\
\hline Mashila ${ }^{1} /$ Shuri $^{3}$ & Sorghum bicolor & $\checkmark$ & $\checkmark$ & & & & & & & & & & \\
\hline Boqollo $^{1}$ & Zea mays & & & & & & $\checkmark$ & $\checkmark$ & $\checkmark$ & $\checkmark$ & & & \\
\hline Mango $^{1}$ & Mangifera indica & $\checkmark$ & $\checkmark$ & & & & & & $\checkmark$ & & & & \\
\hline Avocado $^{1}$ & Persea americana & $\checkmark$ & $\checkmark$ & $\checkmark$ & $\checkmark$ & $\checkmark$ & $\checkmark$ & $\checkmark$ & $\checkmark$ & $\checkmark$ & $\checkmark$ & $\checkmark$ & $\checkmark$ \\
\hline Mechi $^{1}$ & Guizotia scabra & & & $\checkmark$ & $\checkmark$ & & & & & & & & \\
\hline Adey abeba ${ }^{1}$ & Bidens pychloma & $\checkmark$ & $\checkmark$ & & & & & & & & & & \\
\hline
\end{tabular}

Source: own data

${ }^{1} \sim$ Amharic names

${ }^{2} \sim$ the plant names in Shekigna/Sheka language

${ }^{3} \sim$ the plant names in Mejang language 


\subsection{Opportunities and Constraints in Honey Production System in Godere District}

In this study the respondents have identified major opportunities and constraints of the beekeeping subsector of the study area. The summary of the major opportunities include long experience of traditional beekeeping, huge natural resource base, relatively higher productivity of honeybee colonies and increasing demand and hence increasing price of honey. The price of crude honey had been demonstrating continuous increment in recent years in and around Meti town (Figure 2).

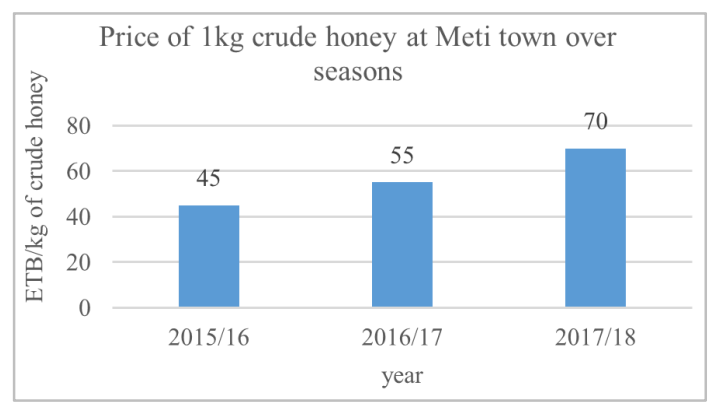

Figure 2. Trend of price of crude honey over three seasons at Meti town.

On the other hand, the major constraints of beekeeping in Godere district identified were practice of traditional forest beekeeping, poor provision of beekeeping extension services and lack of beekeeping technologies and equipment supply. Moreover, poor harvesting and postharvest management is a serious problem. Extraction/straining methods of crude honey were not recognized by the beekeepers. The storage conditions and the marketing structure and function are very poor. The honey containers listed by the beekeepers include plastic bags (used for chemical fertilizers, 46.2\%), plastic bucket $(24.6 \%)$, jerry cans $(21.3 \%)$, the rest use containers like cans and local containers called gourd. All the respondents reported selling $93.25 \%$ of their crude honey in nearby markets, only saving the rest. $94.4 \%$ of respondents sold their honey immediately after harvest. $76.2 \%$ of the honey producers sold their honey in the nearest local market, while the rest was transported to Meti town. Local honey collectors and tej brewers accounted for $82.45 \%$ and $16.32 \%$ of honey buyers in Godere district, respectively.

\section{Discussion}

This study indicated that beekeepers are mostly engaged in their young age. Previous reports revealed average age of beekeepers 40.5, 40.47, and 33 years in Gera, Gomma and two Gambella districts, respectively [5, 13, 14]. This is a good opportunity for the subsector in the area because people in the most productive age are actively engaged in beekeeping activities. Hence, this might be an indication of the sustainability of beekeeping for the generations to come. Nevertheless, beekeeping in the study area is completely gender biased towards male, as previously reported in different areas [5, 13-15]. Only very slight differences, $98.3 \%$ and $96 \%$ around Burie and in Tigray, respectively were reported earlier $[16,17]$. This is may be, mainly due to the nature of dominant forest beekeeping type being practiced that requires travel for long distances into forests, hang log hives on tall trees, which excludes women as it is not culturally/ socially accepted for women to climb trees [5].

The beehive holding of the beekeepers showed that almost all respondents use only traditional log hives. The average number of traditional beehive holdings ( 28 beehives) shows significant differences from what was reported from around Burie ( 8 beehives) and from Gera area (64 beehives) $[5,16]$. No beekeeper was practicing exclusively using transitional or frame hives. In fact only 27 frames hives and 16 transitional beehives were reported to exist by the beekeepers that account only for about $1.25 \%$. They have been using log hives to bait swarm colonies and honey production. The log hives used in the area are made of different tree species. The Mejang make their log hives from Cordia africana that measures about 2 to $2.5 \mathrm{~m}$ in length. According to the beekeepers, this log hive type has better durability compared to similar one but made from logs of Croton macrostachyus, by the highlanders called "korsho" (Figure 3).

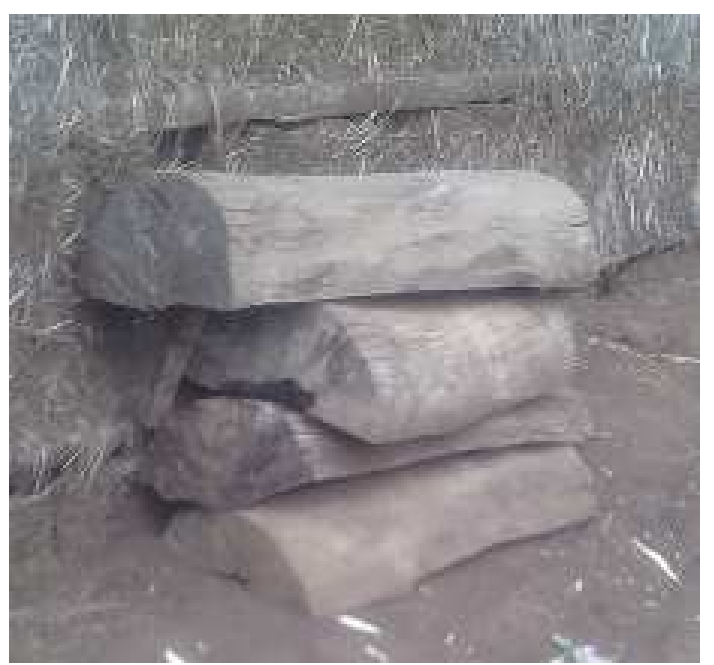

Figure 3. Logs prepared from Croton macrostachyus for traditional hive (korsho) making, at kabo kebele.

Vegetation characteristics of a region are considered to be an important indicator of its beekeeping potential. Identification of the honeybee plants and assessing their abundance, their service to bees, time of blooming and flowering period have a paramount importance for practical beekeeping and in assessing the potential of an area for beekeeping as well as in planning appropriate seasonal management [18]. In terms of species composition and area coverage, Godere district is very rich as there are many species of natural and cultivated plants valuable to bees and honey production, very similar in composition to what had been reported from Gera and two Gambella districts $[13,14]$. However, it should be noted that the floral calendar of an area usually varies from year to year since flowering depends 
on the weather conditions $[18,19]$. Moreover, the occurrences and density of each plant are determined by altitude gradations. Hence, the major honeybee plants mentioned by the respondents from Meti Zuria and Kabo showed some variations as the two kebeles have visible differences in vegetation characteristics.

In Godere district beekeeping is a long time traditional and very extensive practice for the members of indigenous Mejang ethnic group. More than $90 \%$ of the households of Mejang keep bees. According to the information from the District Agricultural Development Office, beekeeping contributes to the major proportion of household income for the indigenous communities. Even for the highland settlers, beekeeping is the second important agricultural activity next to coffee and spice production [10]. However, only very limited effort was made to improve the beekeeping situation and hence, the production system can be categorized totally as traditional forest beekeeping type that passes from generation to generation with little or no improvement. In this survey, only two backyard apiaries were reported to exist and visited, one at Meti Zuria and one at Kabo (owned by group of 12 men) (Figure 4). According to the respondents, preparation and hanging several log hives every season may require staying weeks in the forests away from home and are mostly done in groups of friends or relatives. It was common to see the Mejang men walking long distances carrying their reserve food and water, hunting spears and bows while on their journey to "bereha", the harsh lowlands where they hang the log beehives.

In the study area, it seems the traditional forest beekeeping system has severely limited access for frequently visiting colonies due to distance and need of climbing tall trees to make inspections and other seasonal management practices. There is no practice of any form of colony inspection (external and/or internal), swarm control, disease and pest control, feeding colonies during food shortage, etc. The contradiction is, however even among those who started backyard beekeeping, colony inspection and practices of seasonal colony management activities are almost nonexistent [14]. The respondents knew that colonies issue swarms twice a year. However, the majority ( $\sim 63 \%)$ of hive preparation and swarm trapping is done from mid-September to mid-October which they believe are good to catch; and they ignored swarms issued in February. This needs scientific investigations to clarify their beliefs and if there are differences between the swarms of the two seasons.

In Godere, there are 2 to 3 honey harvesting seasons dictated by both natural and human factors. Specifically, in Meti Zuria the Mejang harvest the major production during March-April from the major honey plant called "Gommo" /kerero in Amharic/ A. adolfi friedrichi that flowers between December and February. This is followed by another honey harvest season starting in late May and extending through June. This time the bees collect nectar from plants like "Somay"/ A. schimperiana/, "Wanza"/C. africana/ and other minor species. On the other hand, the highlanders harvest 3 times a year. The major honey harvesting season is April-
May, after the major honey plant called "Getema"/ $S$. abyssinica flowers in March and April. This is followed by another important honey flow season in June, which is produced from honey plant called "Bisana"/ $C$. macrostachyus. Moreover, near forest edges and in cultivated lands, honey plants like "Mechi"/ G. scabra/ and "Adey abeba"/B. pychloma/ produce significant amount of multifloral honey during November-December. However, the potential of the diversified forest and woody vegetation in the district is believed to support the production of more monofloral honey that can be harvested more than 3 times/harvesting seasons if the beekeepers exercise appropriate seasonal colony management practices.

The manner of removing honey from the hive plays great role in maintaining honeybee colonies from one season to the next. In this regard, the key informant and group discussions revealed that honey harvesting practice has clear differences between the communities of the two kebeles. The Mejang community members have better practice of honey harvesting than the highlanders. This is because they do not drop their beehives from the trees and do not shake the bees off the hives and abandon them. They only remove the honey from the log hives as much as they can access with their arms in the long log hives. Therefore, a significant amount of reserve food is left for the honeybees in the following dearth seasons when they face shortage of food. In such practice, a single colony can survive over multiple seasons and serves for a number of years which is good for higher productivity and conservation of honeybees.

All the participants of the key informant and group discussions of the highland communities reported that they practice honey harvesting in very different manner. Harvesting is done by dropping the log hives from the trees, shaking off the bees to the ground and total removal of the hive content, leaving the colonies to absconding. Then, they collect and pile their empty hives at one place to be used for the next swarming season. This destructive practice means that a colony exists for one harvesting season only. Moreover, this practice highly affects the quality of the honey as all the contents of the hives are mixed. The practice of abandoning colonies after honey harvest is contributing for the losses of thousands of honeybee colonies annually. So, every year beekeepers have to start by catching new swarm colonies that lowers the productivity of the colonies as the bees face shortage of time to build their population in time to take advantage of the nectars available in their surroundings for honey production.

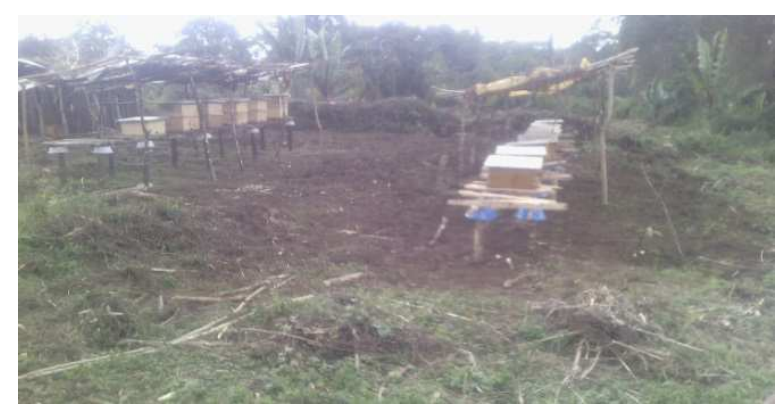




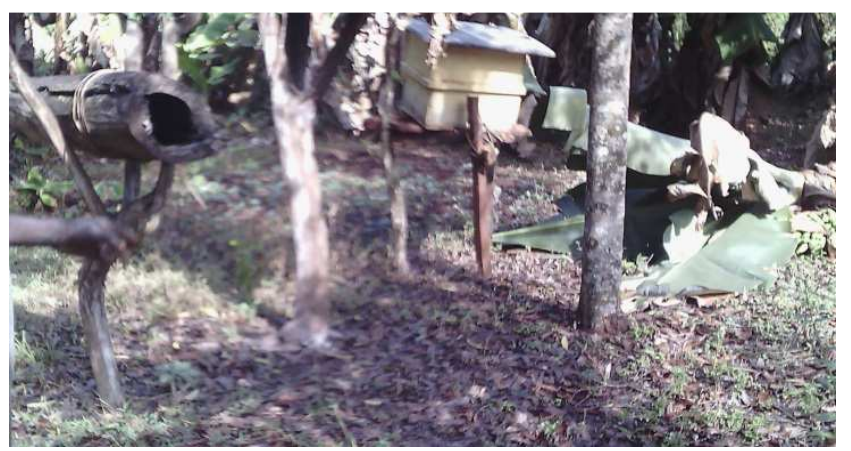

Figure 4. Backyard apiaries (left) at Kabo, group of men own some hives (right) at Meti Zuria, individual beekeeper.

The southwestern part of Ethiopia is known for its high honey production compared to any other parts of the country [1]. The case of Godere district proved to be not different. The average honey yield of traditional hives according to the District Agriculture and Rural Development Offices estimation is $18 \mathrm{~kg} /$ hive/annum [10]. However, the average yield of $24.2 \mathrm{~kg} /$ hive / year from traditional hive reported in this study is significantly higher than what is considered as national average productivity for traditional hives, $7.27 \mathrm{~kg}$ crude honey/hive/annum and a lot of previous reports even from the potential areas [2, 13, 15, 20]. Even though few frame and transitional hives are owned by interviewed beekeepers no yield data were available on the productivity of the colonies in these hives. However, this high maximum honey yield potential in the traditional beehives, $40 \mathrm{~kg} /$ colony/annum, suggests the existences of high possibilities of maximizing the yield through introducing improved beehives with appropriate seasonal management of honeybee colonies.

The beekeeping subsector of Godere district has a lot of opportunities, which can be tapped and can serve as means of improving the livelihoods of beekeeper households. Among these long experience of traditional beekeeping of the Mejang and the neighboring indigenous communities from the South Nations and Nationalities Regional State (SNNPR) areas is one of the important ones. Moreover, the huge natural resource base, as more than $40 \%$ of the land is covered with natural forest makes bee forage available in most months of the year. The beekeepers reported that they faced no swarm shortages so far and they actually catch swarms in two different seasons a year. This area is among few regions where honey can be harvested three times a year. However, it is not only the frequency of harvest that is higher but also the productivity of colonies. Production of $24 \mathrm{~kg} /$ hive $/$ year is by far higher than the national average $7.27 \mathrm{~kg}$ [2]. This is attributed to many factors, in addition to the availability of food to the bees, such as the hive volume and the honeybee races/ecotypes among others. The other driving factor to encourage honey production in the area is trend of increasing demand for honey and beeswax. In this study all the respondents indicated that the demand for honey has seen constant rise over the last few years. Previous reports also showed similar trend both in the domestic and international markets $[5,13]$. Consequently, the price of the honey and beeswax in the country has been rising. Similarly, in Godere district the respondents have indicated that price for crude honey is increasing.

On the contrary, the huge potential of beekeeping in Godere district is underutilized due to so many constraints. The production system of the area is totally forest beekeeping where log hives are hung on tall trees. This hindered practice of colony inspection and seasonal management operations. Moreover, honey harvesting is brutal and destructive to the colonies as the bees are chased away and all the contents of the hive are removed. Had it been in backyard, sustaining colonies over seasons and better quality of honey would have been attained even using the traditional hives.

Provision of extension services to the beekeepers is one of critical shortcomings in Godere district as the extension system gives little attention to beekeeping. It also lacks all the technical capabilities, logistics and facilities to address the problems of the beekeepers. Beekeepers addressed through different trainings and the advisory services by the District Agriculture Development Office is insignificant. Regarding sufficient beekeeping knowledge and skills, only $12 \%$ of the respondents in Meti Zuria and about $26 \%$ of the respondents in Kabo kebeles reported attending only 1 to 3 days training once. This has resulted in less than $1 \%$ beekeepers practicing backyard beekeeping and low level of application of improved beekeeping equipment, use of protective clothes and harvesting and postharvest materials. This is associated with limited access of beekeepers to the supply points and/or chains of improved beekeeping equipment, other accessories and inputs. There was no active input supplier during the study period in the district or nearby towns like Tepi and Masha and a few frame box hives in the hands of the beekeepers were bought from producers in Mizan Teferi or Jimma towns.

Honey harvesting and postharvest handling in Godere district is entangled with a lot of problems and mismanagement practices. It is very likely that unripe honey is harvested as the beekeepers have no opportunities to inspect the honey before harvesting, which results in beginning of early fermentation and quality loss. The honey is also removed from the hive with a lot of dead bees and brood that leads to fast deterioration of quality (Figure 5). This study also revealed that honey processing knowledge, skills and practices were non-existent at the producers' level. No respondent knew about or practiced any honey extraction/straining methods. Therefore, they sell only crude honey to the nearest village markets or Meti town. Similarly, the honey containers: plastic bags, plastic bucket, jerry cans, etc used by the beekeepers to store and transport are substandard to maintain honey quality. Similar low quality containers used by producers were reported from West Amhara region and from Gambella $[14,16]$. These containers are not appropriate for storage as they result in serious quality deterioration and poor hygiene; hence lead to issues of food safety.

In Godere, just like any other honey producing areas in Ethiopia, honey is a cash crop and most of what the 
beekeepers produce (about 80-90\%) was brought to market for income generation [16, 17, 21]. In this study the respondents reported selling about $93 \%$ of their produce (totally crude honey) in nearby markets, only saving the remaining small amount for home consumption and medicine. It was found out that $94.4 \%$ of respondents sold their honey immediately after harvest, while the remaining $5.6 \%$ stored for more than a month. Similarly, very short storage time before marketing was reported in Gambella Zuria and Godere districts [14]. Longer storage time was reported earlier. $75 \%$ of the respondents stored their honey 1 to 6 , while $6.7 \%$ stored 7 to 12 months in Gomma district [13]. In Sekota $55 \%$ of the respondents stored their honey for less than a month and about 30\% stored for 1-12 months before supplying to market [22]. Around Burie, in western Amhara, $53.4 \%$ of the producers sold their honey immediately while $28.8 \%$ sold within a month after harvest [16]. Selling immediately after harvest when markets are flooded with honey forces the beekeepers to take lower price. They sell the largest proportion of their honey during harvest at low price mainly to meet their demand for cash to pay taxes, debts and other social obligations [23].

In most of the cases, domestic honey market starts at the smallholder beekeepers level when they sell crude honey to collectors in the nearest village markets who show up during honey harvesting seasons $[8,13,16,17]$. In this study also, it was found that honey producers largely sold their honey in the nearest local market (76.2\%). Only less than $24 \%$ of the respondents transport their honey to the district town (Meti) using pack animals looking for better prices. The distance of the village markets from Meti town are about $15-20 \mathrm{~km}$. However, the price assessment showed as high as $70 \%$ price difference between the two market locations. The two major honey buyers reported by the producers are the collectors $(82.45 \%)$ and tej brewers $(16.32 \%)$ in Godere district. The collectors play significant role in assembling and distribution of the honey within and outside the district. According to the Godere district Agriculture Products Marketing Department, who provides permit for the transport honey out of the area, 85 people had certificate to buy and transport honey. In 2017/8 April- June harvest season only, they estimated about 230 tons of honey was moved from the district to other destinations, as far as to Addis Ababa (personal communication).

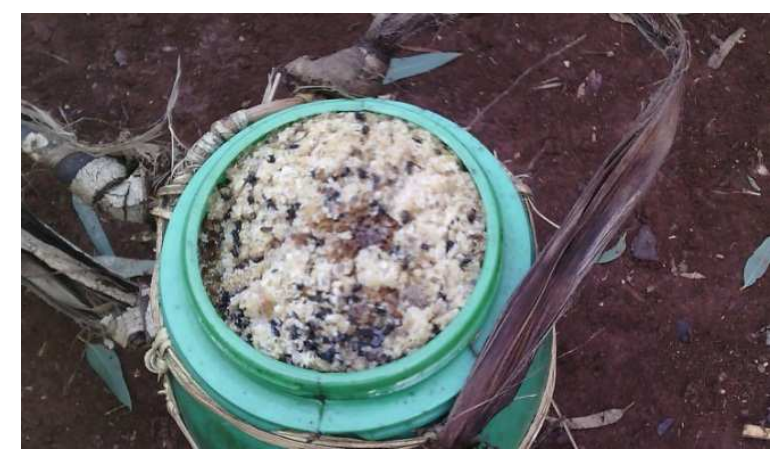

Figure 5. Crude honey with a lot of dead bees and hive debris ready for sale at rural village market, Meti Zuria.

\section{Conclusion}

This study clearly underlined that beekeeping in Godere district particularly in the study sites had huge potential in availability of honey bee flora, enormous number of feral and hived colonies, long culture of beekeeping experience that is socially valued and has big share of household economy. The productivity of the colonies in traditional hives is also significantly higher compared to any previous reports in Ethiopia. The ever increasing price of honey in the local markets is also an opportunity of the subsector. However, the whole honey production system is traditional forest beekeeping with no interventions to bring it to backyard apiaries, transform to improved beehives and application of other improved beekeeping accessories. The harvesting, storing, transporting and marketing of the produce is totally inefficient and susceptible to losses in quantity, quality and profitability. Therefore, systematic approach to tackle all the problems in the whole honey value chain, starting from supply of inputs, technical knowledge and skill development to the postharvest management and marketing is critically needed to transform and exploit the existing honey production potential in Godere district.

\section{Acknowledgements}

The authors would like to thank Godere District Agriculture Development Office and experts for their cooperation during data collection and to beekeepers in the study area for willing to be interviewed and giving us all valuable information. We also extend our thanks to Technoserve Ethiopia, Godere field Office and its workers. This research was supported by Technoserve Ethiopia, Addis Ababa.

\section{References}

[1] Adgaba N. Atlas of pollen grains of major honeybee flora of Ethiopia. Holeta Bee Research Centre. Commercial Printing Enterprise. Addis Ababa, Ethiopia. Pp 152. 2007.

[2] CSA. Statistical Abstracts. Central Statistical Agency. Addis Ababa, Ethiopia. 2017.

[3] MoARD. Livestock Development Master Plan Study. Phase I Report - Data Collection and Analysis, Volume N Apiculture. Addis Ababa, Ethiopia, Ministry of Agriculture and Rural Development. 2007.

[4] FAO. Statistical yearbook, FAOSAT. 2008.

[5] Assefa M. Pro-poor value chains to make market more inclusive for the rural poor: Lessons from the Ethiopian honey value chain. Danish Institute for International Studies, Copenhagen, Denmark. Pp. 35-50. 2011.

[6] GDS. Integrated Value Chain Analyses for Honey and Beeswax Production in Ethiopia and Prospects for Exports. The Netherlands Development Organization (SNV). 2009.

[7] Igram, V. Bees, Trade - and Success. LEISA Yaounde, Cameroon, Center for International Forestry Research (CIFOR), c/o IITA Humid Forest Ecoregional Centre, B. P. 2008. 
[8] Legesse G. Honey production and marketing in Ethiopia. Agriculture and Biology Journal of North America, 2016: 7: $248-253$.

[9] CSA. Statistical Abstracts. Central Statistical Agency. Addis Ababa, Ethiopia. 2013.

[10] GDARDO. Godere District Agricultural and Rural Development Office, Annual report, Metti, Ethiopia. 2011.

[11] Alemu B, Hundera K, Abera B. Floristic composition and structural analysis of Gelesha forest, Gambella regional State, Southwest Ethiopia. Journal of Ecology and the Natural Environment, 2015: 7: 218-227.

[12] Yeshitela K. Effects of anthopogenic disturbance on the diversity of Foliicolus lichens in tropical rainforests of East Africa: Godere (Ethiopia), Budongo (Uganda) and Kakamega (Kenya). Cuvillier Verlag Gottingen. Pp 173. 2008.

[13] Kinati C, Tolemariam T, Debele K. Assessment of Honey Production and Marketing System in Gomma District, South Western Ethiopia. Greener Journal of Business and Management Studies, 2013: 3: 99-107.

[14] Shibru D, Asebe G, Megersa E. Identifying Opportunities and Constraints of Beekeeping: The Case of Gambella Zuria and Godere Districts, Gambella Regional State, Ethiopia. Entomology, Ornithology and Herpetology: Current Research, 2016: 5: 1-6.

[15] Tesfa A, Ejigu K, Kebede A. Assessment of Current Beekeeping Management Practice and Honey Bee Floras of Western Amhara, Ethiopia. Inter J Agri Biosci, 2013: 2: 196201.

[16] Belie T. Honeybee production and marketing systems, constraints and opportunities in Burie District of Amhara Region, Ethiopia. A Thesis Submitted to the Department of
Animal Science and Technology, School of Graduate Studies, Bahir Dar University. Bahir Dar, Ethiopia. 2009.

[17] Abebe A. Market chain analysis of honey production: in Atsbi Wemberta district, Eastern Zone of Tigray National Regional State. A Thesis Submitted to College of Agriculture, Department of Agricultural Economics, School of Graduate Studies Haramaya University, Haramaya, Ethiopia. 2009.

[18] Adgaba N, Hepburn, HR. Pollen grains of some poisonous bee plants of Ethiopia. Proceedings of the 37th International Apiculture Congress, 28 October-1 November, 2001, Durban, South Africa. 2001.

[19] Gichora M. Towards Realization of Kenya's Full Beekeeping Potential: a Case Study of Baringo district. Ecology and Development Series No. 6, 2003. Cuvillier Verlag Gottingen, Germany. 2003.

[20] Awraris G, Hailemariam G, Dejen A, Zerihun T. PhysicoChemical properties of honey produced in Masha, Gesha and Sheko districts in Southwestern Ethiopia. Current Research in Agricultural Sciences, 2014: 1: 110-116.

[21] Hartmann, I. The management of resources and marginalization in beekeeping Societies of South West Ethiopia. Paper submitted to the conference: Bridge Scales and Epistemologies. Alexandria. P. 1. 2004.

[22] Alemu T, Seifu E, Bezabih A. Postharvest handling, opportunities and constraints to honey production in northern Ethiopia. Livestock Research for Rural Development, 2015: 27 (5).

[23] Tadesse B, Phillips D. Ensuring small scale producers in Ethiopia to achieve sustainable and fair access to honey markets. Paper prepared for International Development Enterprises (IDE) and Ethiopian Society for Appropriate Technology (ESAT). Addis Ababa, Ethiopia, pp 1-64. 2007. 